\title{
Osteochondroma of the sigmoide notch: a case report of an unusual location
}

Ana Reis Durão ${ }^{\mathrm{a}}$, Israel Chilvarquer ${ }^{\mathrm{b}}$, Márcia Provenzano ${ }^{\mathrm{b}}$, José T Koch ${ }^{\mathrm{a}}$, Marcelo Miranda ${ }^{\mathrm{a}}$, Aline Cantarelli Morosollic

\section{ABSTRACT}

Objective: This article presents an interesting case of osteochondroma of the the sigmoid notch. Case Report: A 15-year-old female with severe facial asymmetry, malocclusion, open bite and extreme limitation of mouth opening. Panoramic radiography showed an exophytic radiopaque mass arising from the sigmoid notch on the right side. CT images revealed bony proliferation with benign signs causing damage to the articular eminence, condilar morphology and periarticular soft tissue calcifications. Magnetic Resonance confirmed the findings of the CT and revealed modifications on disc morphology. A surgical resection was performed.

Conclusion: The OC located at the sigmoid notch presented is probably the rarest site seen in the existing literature.

Key words: Osteochondroma; Sigmoid notch; Facial asymmetry; Restricted mouth opening

\section{Osteocondroma do sulco sigmoide: relato de caso em uma localização rara}

\section{RESUMO}

Objetivo: O presente artigo apresenta um caso interessante de osteocondroma (OC) no sulco sigmoide. Relato do caso: Paciente do sexo feminino, com 15 anos de idade, apresentada assimetria facial severa, mal oclusão, mordida aberta e restrição severa da abertura bucal. A radiografia panorâmica evidenciou a presença de uma massa radiopaca exofítica, partindo do sulco sigmoide do lado direito. Imagens de tomografia computadorizada (TC) evidenciaram a presença de proliferação óssea, com características benígnas, causando alterações na eminência articular, morfologia condilar e calcificação dos tecidos moles peri-articulares. A ressonância magnética confirmou os achados da TC com relação à alteração da morfologia do disco articular. Como tratamento, foi realizada a ressecção cirúrgica.

Conclusão: O OC localizado no sulco sigmoide, apresentado no presente relato de caso, é provavelmente a localização mais rara citada na literatura.

Palavras-chave: Osteocondroma; Sulco sigmoide; Assimetria facial; Restrição de abertura bucal a Faculty of Dental Medicine, University of Porto Porto, Portugal

b University of São Paulo, São Paulo, SP, Brazil

Dentistry School, Pontifical Catholic University of Rio Grande do Sul, Porto Alegre, RS, Brazil 


\section{INTRODUCTION}

Osteochondroma (OC), or osteocartilaginous exostose, is a benign tumour of mature hyaline cartilage, most commonly found at the ends of long bones $[1,2,3]$. They represent 20 to $50 \%$ of benign bone tumors and $10 \%$ of all bone tumors [4]. When large enough, OCs located at the coronoid process can form a joint with the zygomatic arch (Jacob's disease) $[5,6]$. This pseudoarticulation leads to restricted jaw movement, which can clinically be mistaken for temporomandibular joint dysfunction. Mouth opening reduction is the most consistent clinical feature of OC [6]. It's rare in the dentomaxillofacial region [7-10], however, when it occurs, the condyle and coronoid process are frequently the affected sites [7,9-12]. Other locations have been reported such as the skull base, posterior maxilla, maxillary sinus, ramus, body and symphysis $[7,10]$. It has been reported usually at the fourth decade $[9,11,13]$. However, Walford et al. [14] stressed that the second decade is the most suitable for this condition (68\%). It has a female predilection $[4,9,11,14]$, which could indicate a hormonal correlation [14].

Its aetiology remains controversial, as neoplastic, developmental or reparative origins have been discussed in the literature $[15,16]$. Theories are based on the presence of nests of chondrocytes in the periosteum [12]. Mechanical stress may lead to hyperplasia of these cells, because it is usually located in areas such as tendon insertions. On the mandible, especially the condyle, the remains of the Meckel cartilage may be the origin $[3,9,11,16]$. Microtrauma and inflammation have been designated as contributory factors [15-17].

OCs are regularly slow growing, and symptoms develop over a long time. It presents with modifications at the occlusion [7,8,12], development of facial asymmetry, and a posterior apertognathia on the affected side [13], pain with varying intensity $[7,8]$. Limitation of mouth opening is not common with condylar tumors, but is often noticed with tumors located at the coronoid process $[7,13]$.

Radiographically, this tumor appears as an irregularly shaped enlargement of the condyle [13]. Lesion density is often high and uniform with a distinct border. Complementary examinations such as panoramic radiography and computed tomography $(\mathrm{CT})$ can be useful to visualize the existing relationships among anatomic structures [18]. Other useful examination includes scintigraphy to evaluate the presence of multiple lesions [17]. Approximately $75 \%$ of the patients with osteochondroma develop solitary lesions while $25 \%$ have multiple lesions. The definitive diagnosis of $\mathrm{OC}$ is based on clinical, radiographic findings and histological criteria $[8,18]$. Differential diagnosis includes osteoma, chondroma condylar hyperplasia, chondrogenic intracondylar lesion, giant cell tumor, myxoma, fibro osteoma, fibrous dysplasia, fibrosarcoma, osteo cartilaginous exostosis $[7,8,13,18]$, fibrous dysplasia, and metastatic disease [13].

The histological appearance of OC consists in dense chondrocytes interspersed with marrow and fat cells and capped by cartilage of varying thickness, similarly to those of normal epiphyseal cartilage. Endochondral ossification is often seen at the osteocartilaginous junction $[1,8,13]$.

Treatment depends on size, symptom, and growth status [17]. Resection, with or without reconstruction, depends on the defect and associated dentofacial deformity $[4,9]$. Alternatively, a conservative approach can result in an inadequate removal of the tumor and lesion recurrence or enables recurrence or malignant change of the lesion [4]. Recurrence of OC and malignant transformation are extremely rare $[8,11]$, approximately $2 \%$ [7].

No reports were found of OC of the sigmoid notch OC. This article aims to present an OC of the right sigmoid notch seen in a 15-year-old female.

\section{CASE REPORT}

A 15-year-old female was referred to Department of Oral Radiology for evaluation of a severe reduction of mouth opening. The patient presented with increasing mouth opening reduction that has been getting worst over time. The clinical findings were $8 \mathrm{~mm}$ of mouth opening with a deviation to the affected side and malocclusion on the opposite side. Facial asymmetry, malocclusion with open bite on the right were seen. Panoramic radiography showed an exophytic radiopaque mass arising from the sigmoid notch on the right side and altered condilar morphology (Fig. 2). CT images showed a bony proliferation with benign signs arising from the antero-medial side of the sigmoid notch causing damage to the articular eminence, condilar morphology and periarticular soft tissue calcifications (Fig. 3A, 3B and Fig. 4). Magnetic Resonance confirmed the findings of the $\mathrm{CT}$ and revealed modifications on disc morphology (Fig. 5). A surgical resection was performed. Histopathological evaluation confirmed an OC.

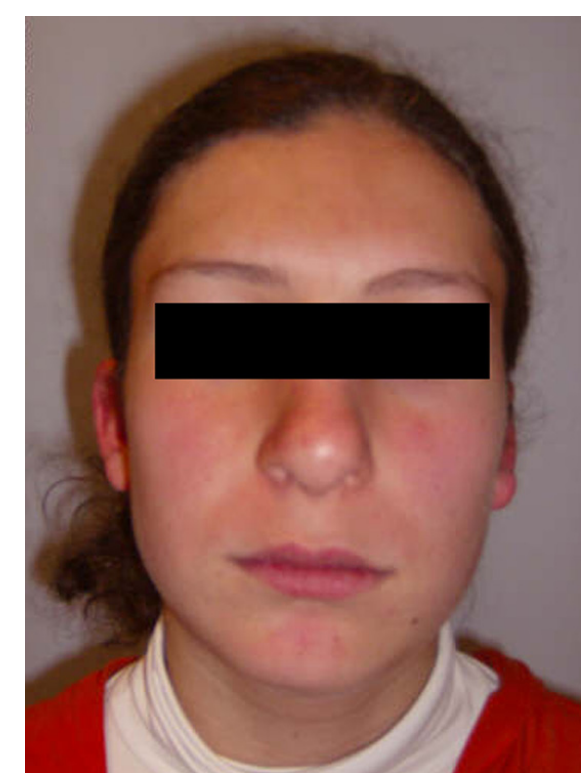

Figure 1. 15-year-old female showed a facial asymmetry. 


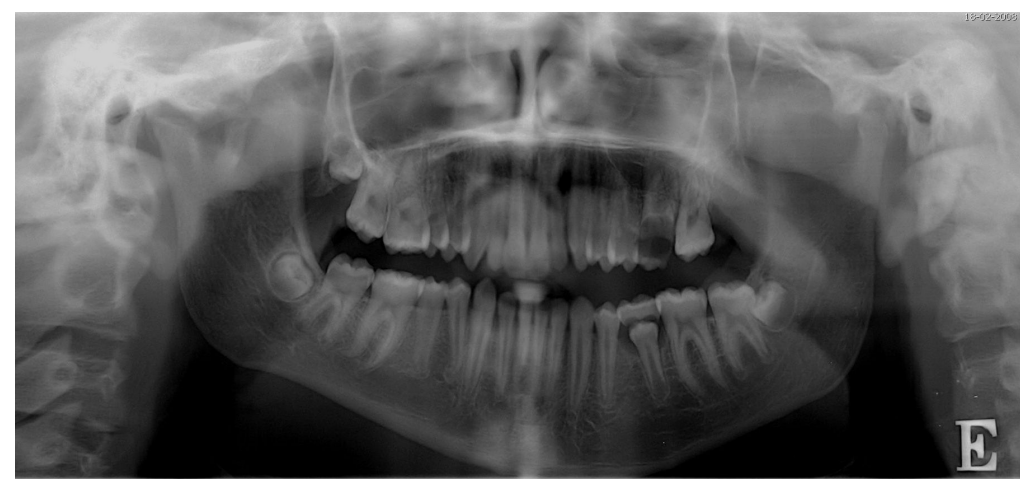

Figure 2. Panoramic radiography showed an exophytic radiopaque mass arising from the sigmoid notch on the right side and altered condilar morphology
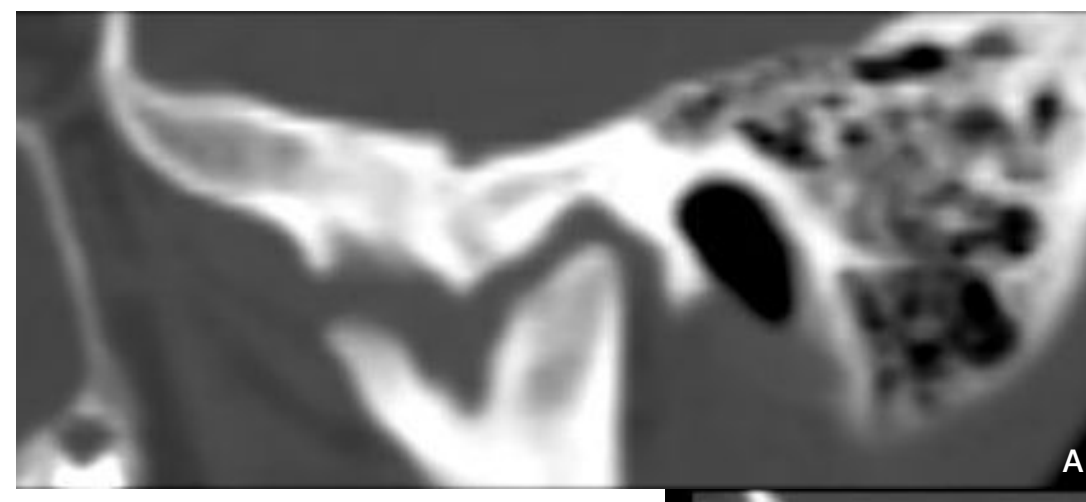

Figure 3A-B. Sagital and coronal CT slices revealed a bony proliferation with benign signs arising from the antero-medial side of the sigmoid notch causing alterations on the articular eminence, condilar morphology and periarticular soft tissue calcifications.
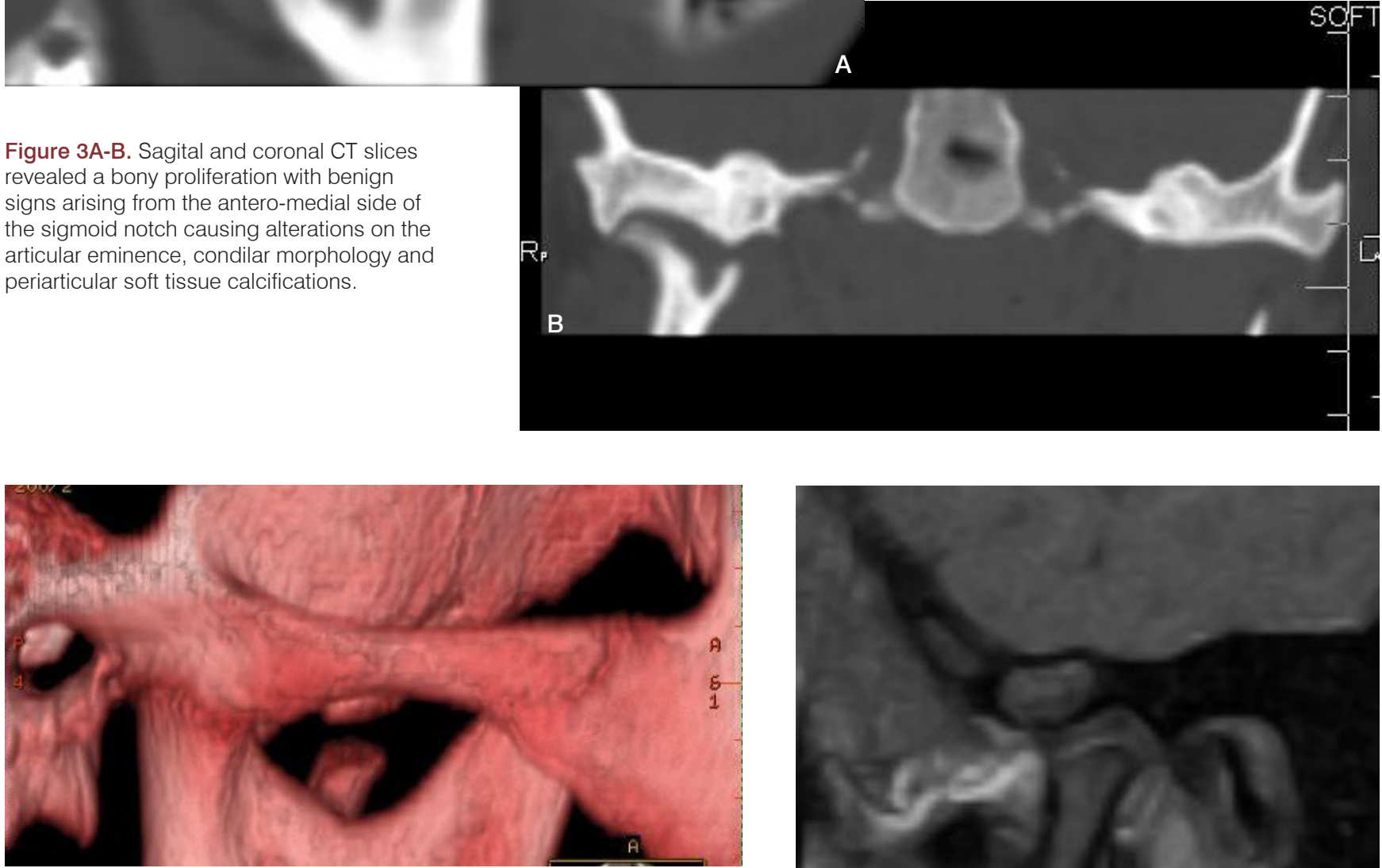

Figure 4. 3D Image of the sigmoid notch on the right side.

Figure 5. Magnetic Resonance confirmed the findings of the CT and revealed alterations of the disc morphology.

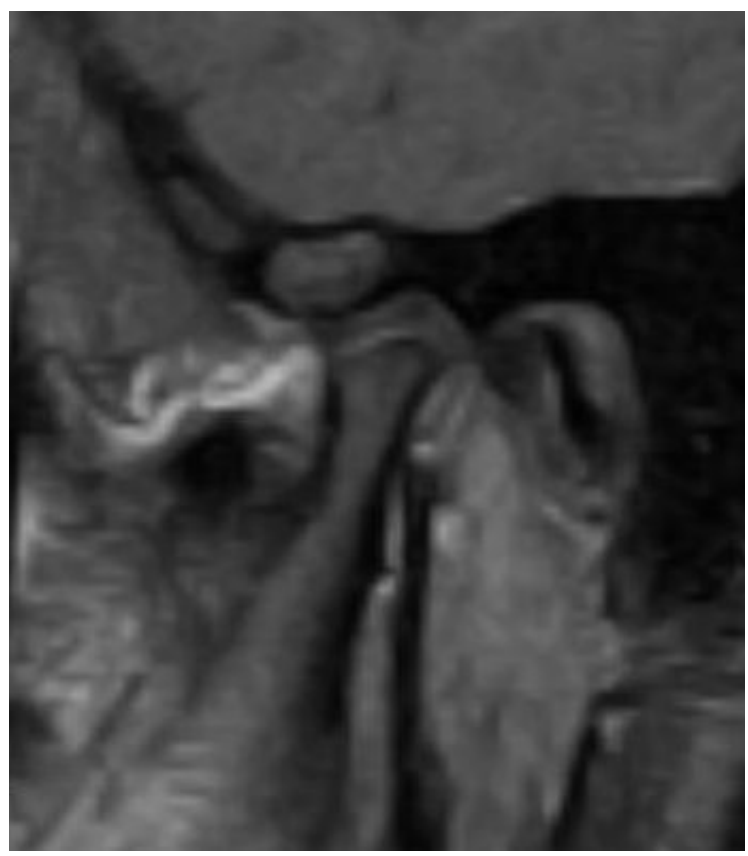




\section{DISCUSSION}

OCs is uncommon in the oro-maxillofacial region. A study more accurate made in 2011 revealed that at least 108 cases had been reported in the English-language literature [17]. However, coronoid process and the medial aspect of the condyle are the most commonly affected areas $[7,9,10,12]$. The OC located at the sigmoid notch presented is probably the rarest site seen in the existing literature. Pathogenesis has been controversial. Nevertheless, the view of aberrant foci of epiphyseal cartilage at the bone surface is currently accepted. This may explain the coronoid process predisposition for its growth. It is still uncertain whether this lesion is developmental, neoplastic, or reparative. Trauma and inflammation have been specifically indicated either as initiating or as predisposing factors for mandibular OCs [7-10].

Patients with OCs commonly present with the following features: facial asymmetry, disturbed occlusion [7,8,12], posterior apertognathia on the affected side, crossbite at the unaffected side, palpable, painless area mass $[7,8,10]$ together with limitation of mouth opening and mandibular movement $[7,13]$. In the present case, patient presented facial asymmetry, malocclusion with open bite on the right side, malocclusion on the left and severe limitation of mouth opening. The growth of an $\mathrm{OC}$ is usually slow, causing gradual displacement and elongation of the mandible $[7,8]$.

Surgeons in the past have given too much attention to lesion resection and restoration of joint function, ignoring secondary facial deformities and associated malocclusion [10]. Relapse is possible $[4,8,9,11]$, although a general recurrence rate of about $2 \%$ has been reported for OCs, no case of either recurrence or malignant transformation has been reported in the mandible $[9,19]$.

Surgical excision of the tumor was performed. There was no sign of recurrence on follow-up for 7 years. A postoperative follow-up with regular clinical and radiographic examination is important to avoid recurrence.

\section{CONCLUSION}

The OC located at the sigmoid notch presented is probably the rarest site seen in the existing literature.

\section{REFERENCES}

1. Ortakoglu K, Akcam T, Sencimen M, Karakoc O, Ozyigit A, Bengi O Osteochondroma of the mandible causing severe facial asymmetry: A case report. Oral Surg Oral Med Oral Pathol Oral Radiol Endod. 2007; 103:21-8. https://doi.org/10.1016/j.tripleo.2006.11.035
2. White SC, Pharoah MJ. Oral radiology: principles and interpretation. 6th ed. Mosby; 2009:500-1.

3. Kumar V. Large osteochondroma of the mandibular condyle treated by condylectomy using a transzygomatic approach. Int. J. Oral Maxillofac Surg. 2009; 39:188-91. https://doi.org/10.1016/j.ijom.2009.12.004

4. Ramos-Murguialday M, Morey-Mas MA, Janeiro-Barrera S, GarcíaSánchez A, Molina-Barraguer I, Iriarte-Ortabe JI. Osteochondroma of the temporomandibular joint: report of 2 cases emphasizing the importance of personalizing the surgical treatment. Oral Surg Oral Med Oral Pathol Oral Radiol. 2012; 113:e41-e47. https://doi.org/10.1016/j.tripleo.2011.07.007

5. Etöz O, Alkan A, Yıkılmaz A. Osteochondroma of the mandibular coronoid process: a rare cause of limited mouth opening. $\mathrm{Br} \mathrm{J}$ Oral Maxillofac Surg. 2009; 47:409-11. https://doi.org/10.1016/j.bjoms.2008.10.021

6. D'Ambrosio N, Kellman R, Karimi S. Osteochondroma of the coronoid process (Jacob's disease): an unusual cause of restricted jaw motion. Am J Otolaryngol-Head Neck Med Surg. 2011; 32:52-4. https://doi. org/10.1016/j.amjoto.2009.09.008

7. Ongole R, Pillai RS, Ahsan AK, Pai KM. Osteochondroma of the mandibular condyle. Saudi Med J. 2003; 24 (2): 213-6.

8. Zhang J, Wang H, Li X, Li W, Wu H, Miao J, X Yuan. Osteochondromas of the mandibular condyle: variance in radiographic appearance on panoramic radiographs. Dentomaxillofac Radiol. 2008; 37:154-60. https:// doi.org/10.1259/dmfr/19168643

9. González-Otero S, Navarro-Cuéllar C, Escrig-de Teigeiro M, FernándezAlba-Luengo J, Navarro-Vila C. Osteochondroma of the mandibular condyle: Resection and reconstruction using vertical sliding osteotomy of the mandibular ramus. Med Oral Patol Oral Cir Bucal 2009; 14; 4:194-7.

10. Li H, Hu J, Luo E, Zhu S, Li J. Treatment of Osteochondroma in the mandibular condyle and secondary dentofacial deformities using surgery combined with orthodontics in adults. J Oral Maxillofac Surg 2014 72:2295-317. https://doi.org/10.1016/j.joms.2014.03.021

11. Peroz, H. J. Scholman, B. Hell: Osteochondroma of the mandibular condyle: a case report. Int J Oral Maxillofac Surg 2002; 31:455-6. https:// doi.org/10.1054/ijom.2002.0234

12. Ribas Mde O1, Martins WD, de Sousa MH, Zanferrari FL, Lanzoni T. Osteochondroma of the mandibular condyle: literature review and report of a case. J Contemp Dent Pract 2007:8(4):52-9

13. Loftus MJ, Bennett JA, Fantasia JE. Osteochondroma of the mandibular condyle. Report of three cases and review of the literature. Oral Surg Oral Med Oral Pathol Oral Radiol Endod 1986; 61:221-6. https://doi. org/10.1016/0030-4220(86)90364-6

14. Wolford LM, Movahed R, Dhameja A, Allen WR. Low condylectomy and orthognathic surgery to treat mandibular condylar osteochondroma: A retrospective review of 37 cases. J Oral Maxillofac Surg. 2014; 72:17041728. https://doi.org/10.1016/j.joms.2014.03.009

15. Meng $Q$, Chen S, Long X, et al: The clinical and radiographic characteristics of condylar osteochondroma. Oral Surg Oral Med Oral Pathol Oral Radiol. 2012;114:e66. https://doi.org/10.1016/j.0000.2012.01.016

16. Singhal A, Venkatpathy R, Singhal P. Condylar osteochondroma: Report of a case with literature review. SRM J Res Dent Sci. 2013; 4:82-5. https:// doi.org/10.4103/0976-433X.120185

17. Roychoudhury A, Bhatt K, Yadav R, Bhutia O, Roychoudhury S. Review of osteochondroma of mandibular condyle and a report of case series. J Oral Maxillofac Surg. 2011; 69:2815-23. https://doi.org/10.1016/j. joms.2010.10.016

18. Utumi ER, Pedron IG, Perrella A, et al: Osteochondroma of the temporomandibular joint: A case report. Braz Dent J. 2010; 21:253-8. https://doi.org/10.1590/S0103-64402010000300014

19. Holmund AB, Gynther GW, Reinholt FP. Surgical treatment of osteochondroma of the mandibular condyle in the adult. A 5-year followup. Int J Oral Maxillofac Surg. 2004; 33:549-53. https://doi.org/10.1016/j. ijom.2004.01.006 